\title{
Exploration on Improvement of Management Mechanism of Counselors in Colleges
}

\section{SHAOPENG}

The College of Fine Arts ,Huaqiao University,Quanzhou Fujian China

\begin{abstract}
The team of counselors is an important organizational assurance and a long-term mechanism to strengthen and improve college students' ideological and political education, Therefore, building a high political quality, strong theoretical background, business ability, high degree of specialization, It is imperative to build a professional team that can ensure the socialist education direction for colleges and universities.
\end{abstract}

Keywords:Counselors in Colleges, Specialization, Professionalism.

\section{完善高校辅导员队伍管理机制的思考}

\author{
吕少蓬
}

华侨大学美术学院, 中国福建泉州

的日常管理、思想教育、素质教育、就业指

摘要:辅导员队伍是加强和改进大学生思想 政治教育的重要组织保证和长效机制, 因此, 建设一支政治素质高、理论功底强、业务能 力精、专业化程度高, 能保证高校的社会主 义办学方向的职业化队伍势在必行。

关键词:高校辅导员; 专业化; 职业化

\section{一、引言}

《中共中央、国务院关于进一步加强和 改进大学生思想政治教育的意见》指出: “大 学生思想政治教育工作队伍的主体是学校党 政干部和共青团干部, 思想政治理论课和哲 学社会科学课教师, 辅导员和班主任。”而 辅导员是学生思想政治教育工作一线的组织 者和管理者, 因此辅导员队伍是加强和改进 大学生思想政治教育的重要组织保证和长效 机制。高等学校的学生辅导员, 承担着学生
导等与学生成长成才息息相关的工作, 是大 学生的人生导师和健康成长的知心朋友, 是 高校正常教学秩序的直接维护者, 是高校校 园文化建设的直接组织者, 是高校校风学风 建设的直接实施者, 是大学精神的直接营造 者和传播者。高校学生辅导员的工作性质和 任务, 决定了这应是一支政治素质高、理论 功底强、业务能力精、专业化程度高, 能保 证高校的社会主义办学方向的职业化队伍。

\section{二、高校辅导员队伍专业化、职业化建设的 必要性}

加强辅导员队伍建设, 关键在于提高辅 导员的基本素质。一个合格的高校辅导员应 掌握较为专业的教育学、管理学和人文自然 学科的知识。掌握教育的基本原理、规律和 方法, 是一个教育工作者应具备的基本素质; 掌握管理学的基本原理和方法, 是一个辅导 
员带好一个团队应具备的基本素质; 掌握较 为丰富的人文自然科学知识, 是高校加强学 生综合素质教育, 培养学生的创新精神和实 践能力对辅导员的基本要求。一个合格的高 校辅导员还应具有较高的政策理论水平、对 学生进行心理咨询的能力和职业指导的能 力。辅导员具有较高的政策理论水平是高校 坚持社会主义办学方向和保证高校培养的人 才成为社会主义建设者和接班人最直接的保 证; 现在的大学生由于独生子女问题、社会 问题、人际交往问题、认知情感问题等诸多 因素的影响, 存在不同程度的心理障碍的学 生已越来越多, 这就要求对学生的成长有着 直接影响的辅导员应较好地掌握心理学的基 本知识和心理咨询的基本方法和技巧，心理 咨询师应作为辅导员的基本条件之一; 如何 认识社会, 如何选择职业, 如何处理好理想 与现实的矛盾, 如何掌握求职的技巧等, 是 现在的大学生在就业过程中普遍遇到的问 题, 辅导员作为大学生就业的主要引导者, 应掌握较为丰富的就业政策、就业信息和较 强的实际指导能力, 职业咨询师也应作为辅 导员的基本条件之一。因此, 对于高校学生 辅导员的建设, 专业化和职业化是加强高校 学生辅导员建设的有效途径。

高校辅导员队伍专业化的内涵:(1)高校 应在思想政治教育专业的基础上, 结合我国 高等教育发展的需要、大学生的特点和辅导 员工作的实际, 开办能培养高水平理论素养 和实践能力的高校辅导员专业, 进行人才培 养和理论研究; (2)从事高校辅导员工作的人 员, 必须经过专业化的理论和实践能力培养, 树立专业意识, 掌握基本的专业技能, 并在 工作实践中不断加强专业的继续学习和培 训; (3)现在高校大多数未经过专业化教育和 培训的辅导员队伍, 应通过各种形式的教育 和培训逐步提高辅导员的自身素质, 并通过 一定形式的认证以满足辅导员工作的实际需 求。

高校辅导员队伍职业化的内涵: (1)从 事高校辅导员工作的人员应经过专业的学习 和培训并达到职业的基本要求, 具备相应基 本知识和基本能力; (2) 高校辅导员工作应 成为一种职业, 保持辅导员队伍的相对稳定 性, 逐步建立辅导员工作的进入、考核、晋
级、淘汰等机制; (3) 应规范高校辅导员的 继续学习和培训, 根据高等教育发展的需要 和大学生的特点对辅导员进行定期的考核和 淘汰。

由于我国高等教育的特殊性, 学生辅导 员除了要对学生提供全方位的咨询和服务 外, 还要加强对学生的教育和引导, 使高校 培养的人才, 真正成为我国社会主义事业的 建设者和接班人, 为逐步实现中华民族的伟 大复兴而自觉承担起高校的历史责任。因此, 加强高校辅导员队伍的专业化和职业化建设 应成为一种必然。

\section{三、高校辅导员队伍现状分析}

笔者曾经对某高校辅导员队伍进行调 研, 该校辅导员总人数为 88 人, 在职称结构 方面: 副教授 2 人, 占 $2.27 \%$; 讲师 25 人, 占 $28.41 \%$; 助教 61 人, 占 $69.32 \%$; 职务结构方 面: 正处 5 人, 占 $5.68 \%$; 副处 9 人, 占 $10.23 \%$; 正科 4 人, 占 $4.55 \%$; 副科 18 人占 $20.45 \%$; 科 员 52 人, 占 $59.09 \%$; 学历结构方面: 研究生 22 人, 占 $25 \%$; 本科 65 人, 占 $73.86 \%$; 其他 人, 占 $1.14 \%$; 年龄结构方面: 35 岁以下 74 人, 占 $84.09 \% ; 36$ 至 45 岁7人, 占 $7.95 \% ; 46$ 岁以上 3 人, 占 $3.41 \%$; 专业结构方面: 理工 21 人, 占 $23.86 \%$; 文科 59 人, 占 $67.05 \%$; 思 政 8 人, 占 $9.09 \%$; 学缘结构方面: 校外毕业 58 人, 占 $65.91 \%$; 本校毕业 30 人, 占 $34.09 \%$ 。 该校辅导员是一支思想政治素质较强, 业务 素质较精, 年富力强, 能独当一面, 特别能 战斗的队伍。可以说该校辅导员队伍是个人 才库, 为各级领导岗位输送了人才。其中担 任校、处级领导就有一二十位来自辅导员队 伍。

但是从以上现状分析却令人担忧。

1. 辅导员的专业化程度普遍不高。毕业 思想政治教育专业较少，仅占 $9.09 \%$ ，大部 分辅导员都是从各个高校各专业毕业后直接 进校的人员，其中许多人没有系统的政治理 论、教育学、管理学、心理学、历史学、职 业咨询等方面的专业知识和实践能力。

2. 辅导员的年龄相对较轻, 经验不足。 35 岁以下 74 人, 占 $84.09 \%$, 由于没有受过思 想政治教育的专业培训, 工作后的专业培训 不够, 缺乏实践工作经验。 
3. 辅导员的业务能力有待提高。辅导员 的业务能力不能完全适应学生的要求, 学生 个人在成长中所遇到的思想困惑、心理障碍、 人际交往、专业学习、发展方向、职业选择 等诸多问题得不到辅导员的正确引导。

4. 辅导员配备不足。该校的辅导员每人 管理的学生达到 300 多人, 甚至多达400-500 人。因此, 对学生的个别教育和群体管理, 对高校校园文化的营造都显得力不从心。

\section{四、高校辅导员专业化、职业化建设的对策}

\section{1. 增强辅导员职业的社会认同}

教育部制定的《高等学校辅导员职业能 力标准 (暂行)》, 明确高等学校辅导员职 业定义为: 辅导员是高等学校教师队伍和管 理队伍的重要组成部分, 具有教师和干部的 双重身份。辅导员是开展大学生思想政治教 育的骨干力量, 是高校学生日常思想政治教 育和管理工作的组织者、实施者和指导者。 辅导员应当努力成为学生的人生导师和健康 成长的知心朋友。高校各级各类人员对辅导 员的角色定位要有全面、准确的认识, 辅导 员既是专业性强、素质要求高的教师, 又是 管理干部。辅导员是以思想政治教育为中心 工作的教师, 但其职责有别于任课老师。从 传统的教师职责的定义 “传道、授业、解惑” 而言, 辅导员是教师; 高校辅导员的工作是 以思想政治教育为主线, 寓教育于学生党建 和团建、日常教育管理与服务以及指导课外 活动中。辅导员在工作中要承担四种职能: 一是教育职能, 即引导学生树立正确的世界 观、人生观、价值观, 树立远大的目标和崇 高的理想, 引导他们正确面对各种 “人生课 题” , 为他们指引正确的成才道路; 二是管 理职能, 即对学生的学习、生活进行规范管 理, 维护校园正常的学习和生活秩序, 协调 学生之间的关系, 建设学生集体; 三是服务 职能, 即关心学生的学习、生活和工作, 代 表和维护学生的正当权益, 做好落实国家资 助贫困生的各项政策, 为学生提供成长成才 指导、就业指导和服务, 帮助学生解决包括 心理问题等实际问题; 四是研究职能, 即以 研究者的姿态参与思想政治教育工作, 开展 调查研究和课题研究, 研究大学生的成长规
律和心理需要, 总结学生教育与管理的经验, 探索思想政治教育工作的规律。这些职能主 要体现思想政治教育的工作性质, 是学校教 育活动的重要组成部分, 其工作内容和方式 方法, 明显不同于任课老师。按照国家有关 文件规定：学生政治辅导员 “是高等学校教 师队伍和管理队伍的重要组成部分”。因此, 高校要按照双重身份对辅导员进行管理, 给 予辅导员以双线晋升职务并享受相应的待 遇, 增强辅导员的职业自信心和职业归属感。

\section{2. 完善辅导员选聘机制}

《教育部关于加强高等学校辅导员、班 主任队伍建设的意见》明确规定: 专职辅导 员总体上按 1 ：200的比例配备, 保证每个院 (系) 的每个年级都有一定数量的专职辅导 员。高校在人事制度改革中, 要认真落实这 一政策要求, 充分考虑学校思想政治教育工 作的实际需要, 科学合理地设置辅导员的岗 位和职数, 既要体现队伍的精干, 又要确保 工作任务得到落实。在选拔标准上, 要根据 教育部制定的《高等学校辅导员职业能力标 准 (暂行)》，按照政治强、业务精、纪律 严、作风正，具备思想政治教育工作相关学 科的宽口径知识储备。具备较强的组织管理 能力和语言、文字表达能力, 及教育引导能 力、调查研究能力等要求。坚持 “五素质” 即思想政治素质、道德素质、知识素质、能 力素质、身心素质; “两优先” 即思想政治 教育专业毕业生优先、具有思想政治教育工 作经验的优先。在选拔方式上, 结合学校学 生工作实际, 采用组织推荐和公开招聘相结 合的办法, 由学校有关领导、组织人事部门、 学生工作职能部门、学院负责人等组成考核 班子, 遵循公开、透明、公正、规范的原则, 借鉴后备干部选拔方式, 对辅导员实行严格、 规范的考核、考试, 特别优秀的可以破格选 拔，对合格的候选人实行任前 “公示制”, 把好入口关。辅导员选聘之后能否得到最优 化的调配, 直接影响着辅导员的工作效率以 及辅导员自身的发展。学校在对辅导员进行 调配时, 坚持两条原则: 一是专业对口, 要 根据辅导员的教育背景和专业特长确定其具 体的工作岗位, 尽可能将他们分配到与其专 业对口的学院, 这样才有利于发挥辅导员的 
专业优势。二是优化组合, 在实践中要充分 考虑辅导员的差异和特征, 将辅导员按照年 龄、性别、学历、专业、个性、经验进行组 合, 取长补短, 合理搭配, 以学院为单位组 建辅导员团队, 从而形成辅导员队伍的整体 优势。

\section{3. 完善辅导员培养机制}

《教育部关于加强高等学校辅导员、班 主任队伍建设的意见》提出: 要制定辅导员 的培训规划, 建立分层次、多形式的培训体 系; 要创造条件, 积极组织辅导员参加社会 实践和学习考察, 提高解决实际问题的能力, 增长做好思想政治教育工作的才干。最近教 育部制定的《高等学校辅导员职业能力标准

(暂行)》规定, 高校辅导员是履行高等学 校学生工作职责的专业人员, 要经过系统的 培养与培训, 具有良好的职业道德, 掌握系 统的专业知识和专业技能。根据这一精神, 高校要制定辅导员队伍建设规划, 统一纳入 学校师资队伍建设规划, 要像培养教学业务、 学术骨干那样, 花大力气培养高水平、高素 质的学生思想政治工作骨干。有计划、有步 骤地安排辅导员参加各种形式的岗前培训和 在岗培训, 对非思想政治教育专业者要进行 严格而比较系统的专业化培训后上岗或边上 岗边培训。通过多种途径, 着力培养学习型 辅导员团队, 不断提高他们的政治理论素养 和政策水平。按照专业化辅导员的素质要求, 对辅导员进行思想政治教育、国际国内时事 政策、心理健康教育知识、法制安全知识、

管理能力、危机事件应对、就业指导和学生 工作技能等专题和培训, 努力使辅导员成为 “思想教育师”、“成才规划师”、“心理 咨询师”、“就业指导师”。组织辅导员开 展思想政治教育调研, 对新形势下学生思想 政治教育出现的新情况、新问题进行研究, 努力争取省级以上思想教育研究课题, 提高 学生辅导员队伍的研究能力。在日常工作中 给辅导员压担子, 交任务, 提供多种锻炼的 机会。同时创造条件, 定期或不定期地组织 他们开展社会考察、社会调查等活动。

\section{4. 完善辅导员考评机制}

完善辅导员考评机制, 对辅导员工作要 进行定期考评，考核其工作实绩：思想政治 工作、日常管理、组织领导、学风建设、指 导活动、就业服务等。制定一套完整的加强 辅导员道德素质建设的总体目标, 以及提高 道德素质的评估内容体系。通过对辅导员道 德素质的评估, 总结经验, 发现问题, 改进 工作，促使辅导员道德工作走上规范化、科 学化的轨道。考核以定性和定量相结合, 定 量为主; 以工作态度、工作能力和工作成效 相结合, 以工作成效为主。通过规范化、科 学化、制度化的考评, 实现辅导员队伍的严 格要求、严格管理, 促进辅导员工作的专业 化、规范化、职业化，促进工作的高效创新。 辅导员的工作面较广, 弹性大, 见效周期长, 为鼓励有良好潜质的辅导员长期从事学生工 作, 高校要通过严格、规范的考核, 对考核 优秀者给予评先评优、晋升职称职务、免试 参加更高学历深造等奖励及激励; 对考评合 格者, 根据个人意向和条件, 结合工作需要 有序地安排换岗交流或进修学习，对考评不 合格者应予解聘转岗。同时, 借助于激励机 制, 挖掘辅导员的道德素质的潜能。高等学 校要卓有成效地运行, 必须使广大辅导员的 积极性和创造性得以充分发挥。这里固然有 许多因素的相互作用, 但合理而有效的激励 机制是不可缺少的。具体来说, 激励机制包 括物质激励和精神激励两方面。因此, 积极 创造条件，提高他们的生活待遇，营造良好 的工作环境, 调动其积极性和创造性是当务 之急。高校要通过分配制度改革, 设立辅导 员岗位津贴, 保证辅导员的收入达到专任教 师的平均水平, 并比同级的行政管理干部高 出一档。较好的住房、较高的经济收入, 是 辅导员工作得到社会承认的标志; 浓厚的学 术氛围、心情舒畅的工作环境, 更有利于激 发辅导员为教育事业而献身的积极性。与物 质激励相比, 精神激励更为重要, 因为心理 认同才是坚定意志内在的和决定性的因素。 如果认识不到这一点, 就会因物质激励迷失 方向, 导致广大辅导员动力缺损、心理失衡、 行为失范, 也难以形成尊重知识、尊重人才 的社会风气。我们的社会主义现代化建设正 处在艰苦的创业时期，伟大的创业实践，需 
要有伟大的创业精神来支持和鼓舞。为此, 要引导广大辅导员坚守思想教育阵地, 牢记 自己的责任, 在教书育人的岗位上实现自我 价值, 把辅导员作为理想的职业来追求并为 之而努力奋斗。

高校辅导员肩负着培养社会主义合格人 才的重任, 辅导员的政治倾向、职业道德以 及对各种社会现象的态度都直接或间接地影 响着学生的成长。因此, 提高辅导员的专业 素质, 加速辅导员的专业化、职业化建设势 在必行。

\section{致谢}

基金项目：华侨大学科研基金（12HSZ08）

作者简介: 吕少蓬 (1960-), 男, 福建泉州 人, 研究员, 主要从事党建和思想政治教育 研究。

通讯方式: E-mail: hqdxlsp@126.com 手机: 13505020895

\section{References}

[1]Wu Peng. Discussion on the specialization and professionalization development of college counselors. $[\mathrm{J}] \quad$ Education and Vocation.2011(05).

[2]Talking on the specialization and professionalization construct of college counselors. [J]Economic Research Guide.2011(17).

[3]Talking on the specialization and professionalization construct of college counselors.Human Resource Development of China. 2011 (01).

[4]Ministry of Education. Opinions on Strengthening University counselor, teacher team building.

[5]Ministry of Education. Professional competence standards of college counselors (Provisional) 2014. 